\title{
SYSTEMATIC REVIEW ON THE PSYCHOMETRIC, RELIABILITY AND VALIDITY PROPERTIES OF TRANSLATED NEUROPATHIC PAIN SCREENING TOOLS (DN4, LANSS AND PDQ) 1 JANUARY 2005 - 19 JULY 2019
}

\author{
T.R. Fagbohun \\ UNIVERSITY OF THE WITWATERSRAND, JOHANNESBURG, SOUTH AFRICA
}

Background. Different neuropathic pain screening tools (DN4, LANSS and PDQ) have been developed, translated into several local languages, and validated. To determine the reliability of these tools and their ability to differentiate between diagnosing neuropathic pain quality from nociceptive pain, a systematic review was conducted to synchronize properties and suggest the reliability of the translated version of these neuropathic pain-screening tools.

Objective. To conduct an evidence-based systematic review to assess the psychometric, reliability and validity of the translated version of DN4, LANSS and PDQ between January 2005 and 2019.

Methods. Two independent reviewers adopted the use of online (Internet) search machine (Pubmed, Scopus and Web of Science) to search for the relevant articles based on JBI (Joanna Briggs Institute) inclusion criteria. Data extracted from the articles were synthesis in tabular form.

Results. Twenty-six articles were included from DN4 $(n=11)$, LANSS $(n=8)$ and PDQ $(n=4)$ translated from English language to eight local languages. The sensitivity and specificity of the DN4 studies ranged from $75 \%$ to $98 \%$ and $37.3 \%$ to $96 \%$, respectively. The internal reliability (a) of the translated version of the DN4 ranged from 0.55-0.862. The sensitivity and specificity of the LANSS studies ranged from $75 \%$ to $98 \%$ and $37.3 \%$ to $96 \%$, respectively. The internal reliability $(a)$ of the translated version of the LANSS ranged 0.67-0.96. The sensitivity and specificity of the PDQ studies ranged from $75 \%$ to $98 \%$ and $37.3 \%$ to $96 \%$, respectively. The internal reliability (a) of the translated version of the PDQ ranged 0.81-0.86.

Conclusions. All the translated instruments reviewed showed good internal consistency of the items, high sensitivity and Positive predictive value (PPV) but not to a suitable level compared with the original version. Therefore, these screening tools are suggested to be used in conjunction with the clinical testing for appropriate diagnosis of patients with neuropathic pain quality.

KEYWORDS: neuropathic pain; positive likelihood; negative likelihood; positive predictive value; negative predictive value.

\section{Introduction}

Neuropathic pain $(\mathrm{Np})$ is classified as one of the worse pains reported by chronic pain patients [1]. An estimated 1 out of 10 chronic pain patients develop neuropathic pain, depending on the population study [2]. The prevalence may be as high as $51.9 \%$ in the patients being managed for chronic pain clinic [3]. Evidence indicates that neuropathic pain affects both physical and emotional state of the patients [4], thereby. This type of pain decreases the quality of life of patients $[4,5]$ and results in a negative interaction with society in general [6]. Neuropathic pain is associated with lesion or disease of the somatosensory pathway that

*Corresponding author: Temitope Richard Fagbohun, Research Student, University of the Witwatersrand, Johannesburg, 2193, South Africa.E-mail: temitopesms@aol.com leads to abnormality observed at the peripheral and central region of the system function (hyperalgesia or allodynia) [7]. The common symptoms associated with neuropathic pain are: sharp, burning, pins and needles, tingling, painful cold, numb and shooting [2].

Diagnosing standards among pain physicians and researchers of neuropathic pain in chronic pain patients have been a challenge [8]. The five Np screening tools are LANSS [9], Neuropathic Pain Questionnaire [10], Douleur Neuropathique 4 'DN4' [11], ID pain [12] and PainDETECT [13]. These instruments have been validated and adapted in different languages from different countries.

Among these instruments, DN4, LANSS and PainDETECT are the most commonly used tools in the assessment of the quality of neuropathic 
pain in chronic pain patients due to their high sensitivity and specificity, short duration of the assessment, easy understanding of the terms and application by the pain experts [14, 15]. Translation of these tools from the original language to local languages is essential for good communication and effective assessment of pain quality between the researcher or pain expert and the patients.

Critically appraising the data measurement of these instruments may be valuable for the clinician and researchers in decision making based on evidence from peer-reviewed articles that adopted these instruments in their studies. Therefore, the aim of this study was to conduct a systematic review on the translated version of the Douleur Neuropathique en 4 Questionnaire (DN4), Leeds Assessments of Neuropathic Symptoms and Signs (LANSS) and the PainDETECT Questionnaire (PD-Q) tools with the objective to evaluate their psychometric, reliability and validity properties.

\section{Methods}

Study design: systematic review of studies was conducted according to PRISMA guidelines [16]. The systematic review was conducted using a developed protocol registered on PROSPERO (CRD42015016752) by the authors. PICO method was adopted to define our study question:

P (Patient or population): Patients with chronic pain

I (Intervention): Diagnostic screening tool

C (Comparator): None

O (Outcome): Psychometric and diagnostic properties of neuropathic pain screening tools: DN4*, LANSS**, and PD-Q ( Includes the DN4interview, ** Includes the self-complete (S)LANSS)

\section{Study Inclusion Criteria}

The following article selection criteria were used:

- Language of publication: No restrictions;

- Geographic location: No restrictions;

- Publication date: 1 January 2005 to 31 July 2019;

- Publication type: Original articles and abstracts;

Search strategy

The search strategy was as follows:

Databases: PubMed, Scopus, Web of Science.

Secondary search: Reference lists of selected publications were checked.

Search terms: ("Douleur Neuropathique" OR DN4 OR DN-4 OR "Leeds Assessment of
Neuropathic Signs and Symptoms" OR LANSS OR PainDetect OR "Pain Detect" OR PDQ or PD-Q) AND pain AND (neuropathy OR neuropathic OR neuralgia OR neuritis OR central OR stroke OR spinal) AND (translation OR adaptation OR validation OR reliability OR validity).

\section{Data management}

Search results were transferred to Mendeley Desktop Reference Manager (Elsevier), where all references retrieved were combined, and duplicates were removed.

\section{Screening}

Initial screening of the articles included was done by title and abstract and was performed by TF (Temitope Fagbohun) and checked by PK (Peter Kamerman). The excluded articles were removed, and the reason for their exclusion was recorded. The full text of all retained studies was then screened by TF and PK and a consensus list of studies was generated to include into the review.

\section{Data extraction}

The following data were extracted:

1. Bibliographic information;

2. Study characteristics:

a. Name of the translated questionnaire;

b. Language of translation;

c. Setting (study population;)

d. Study methods;

e. Measures of reliability (Reliability of the screening tools was determined by the following measures: Test-retest reliability (intraclass correlation coefficient, Pearson's or Spearman's correlation coefficient), inter-rater reliability (Cohen's Kappa lowest and highest score), and internal consistency (Cronbach's alpha));

f. Diagnostic properties (Measures of diagnostic performance: Diagnostic performance was assessed by measures of sensitivity, specificity, positive likelihood, negative likelihood, positive predictive value, and negative predictive value.

\section{Results}

A total of 1,493 articles were obtained from the initial electronic databases search and 27 articles were finally included in the final review. The details of the study identification and selection process in accordance with the Preferred Reporting Items for Systematic Review and Meta-Analysis (PRISMA) statement ${ }^{[16]}$ are described in Fig. 1. One hundred and twenty-two articles were excluded due to duplications. The abstract and the title of 1,371 articles were screened, 1,337 articles were excluded due to not meeting the inclusion 


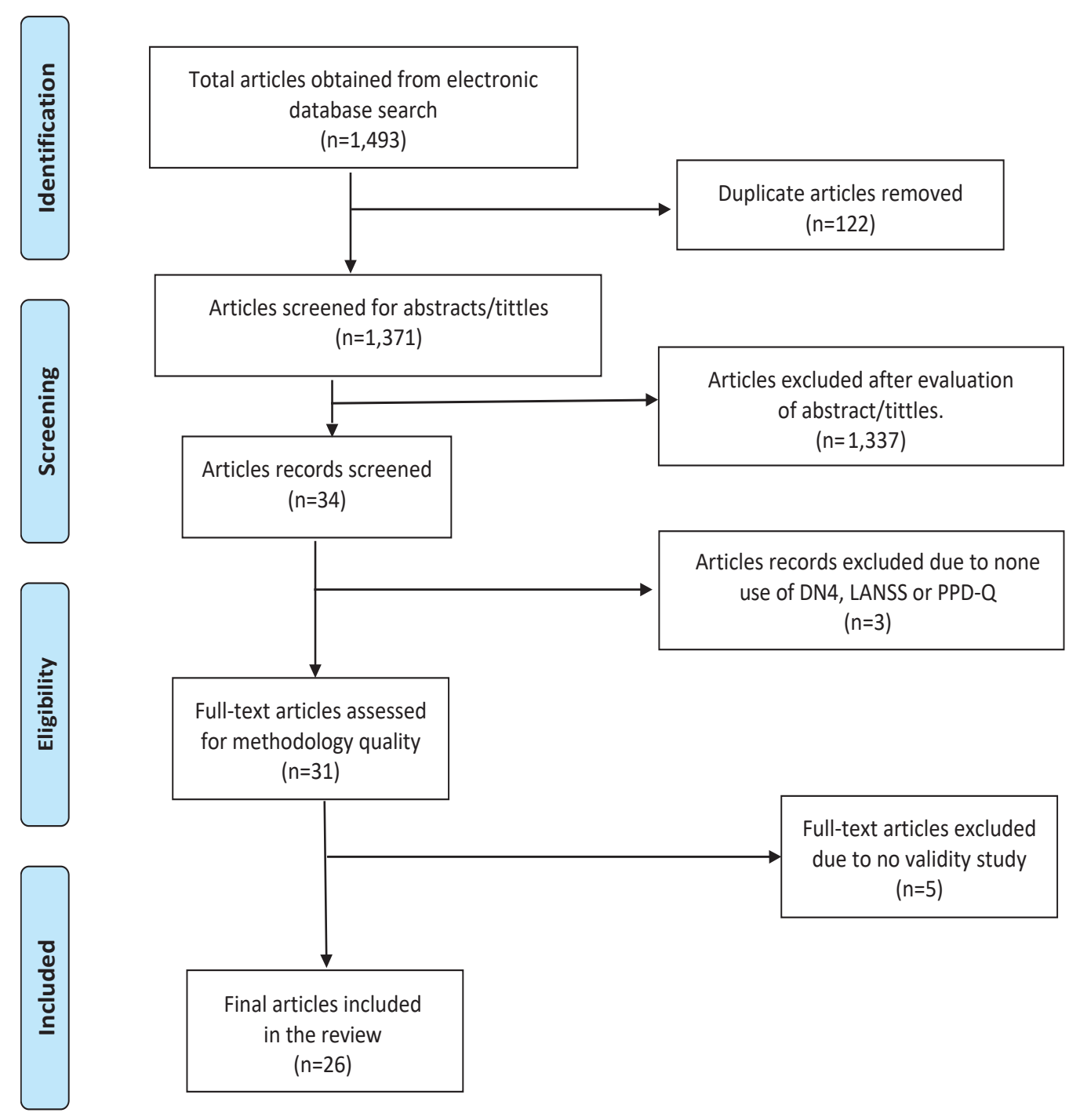

Fig. 1. Flow chart of the final selected articles.

criteria of this study. Thirty-four (34) articles were further screened for full-text inclusion, and three (3) articles were excluded for not applying DN4, LANSS or PainDETECT instrument neuropathic pain screening tools. Thirty (30) articles were further screened for check of validity test; five (5) articles were further excluded due to no validity test. Twenty-six (26) articles were included in this review for extraction.

\section{Summary of the articles included}

Twenty-six articles where included in this review - 11 DN4 articles [17-27], 8 LANSS articles [20, 24, 28-33], 4 PD-Q articles [15, 34-36] and 3 S-LANSS $[28,37,38]$. The total sample size reported was 2,075. Out of this, 1,056 were diagnosed with neuropathic pain, 874 - nociceptive pain and 55 were patients with mixed pain. Eighty-two (82) participants had mixed pain included in the neuropathic pain participants [24] (Table 1).

\section{DN4}

\section{Description of the DN4 articles}

Eleven (11) studies were included in the DN4 screening tool in this review (Table 2). Two (2) studies $[17,21]$ further evaluated the reliability and validity properties of the tools at different cut off. The DN4 was translated to eight different languages which includes: the Arabic language $(n=2)[17,21]$, Brazilian Portuguese $(n=1)[26]$, Korean $(n=2)[19,20]$, Spanish $(n=2)$ $[24,25]$, Farsi $(n=1)$ [22], Greek $(n=1)$ [23], Italian $(n=1)$ [27] and Japanese $(n=1)$ [18]. The total sample size reported $n=1,756$. Out of this, $n=880$ was diagnosed with neuropathic pain, $n=731$ nociceptive pain and $n=55$ were patients with mixed pain. Eighty-two (82) participants had mixed pain included in the neuropathic pain 


\begin{tabular}{|c|c|c|c|c|c|c|c|c|c|c|c|c|c|c|c|c|}
\hline 亭 & 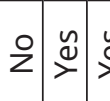 & 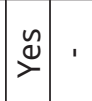 & . & 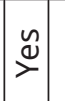 & $\tilde{z}$ & $\stackrel{\varpi}{\nu}$ & 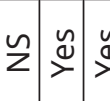 & 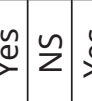 & 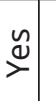 & 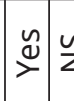 & & $\dot{2} \vec{c}$ & $\hat{v} \stackrel{2}{2}$ & & $\{\stackrel{\check{\nu}}{\rightleftharpoons}$ & 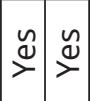 \\
\hline 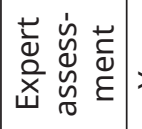 & 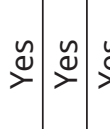 & 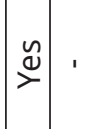 & 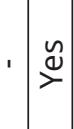 & 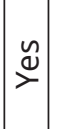 & $\tilde{z}$ & 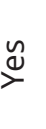 & 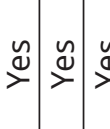 & 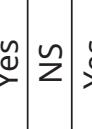 & 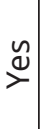 & 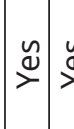 & y & $\stackrel{\searrow}{\supset}$ & 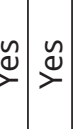 & $\stackrel{y}{\grave{d}}$ & 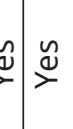 & 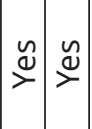 \\
\hline 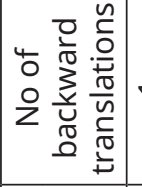 & $-\bar{z}$ & $\sim$ & $\Sigma$ & $m$ & $\underline{z}$ & N & $\sim \sim$ & $v \underline{z}$ & - & -7 & - & - & $\tau$ & $\sim$ & N & $\sim \sim \tilde{z}$ \\
\hline 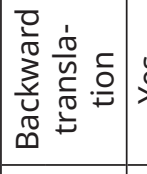 & 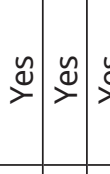 & 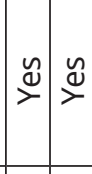 & 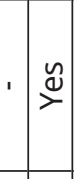 & $\stackrel{\tilde{D}}{\rightleftharpoons}$ & $\underline{n}$ & & & $\Sigma$ & 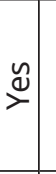 & & $\stackrel{\varrho}{\varnothing}$ & & 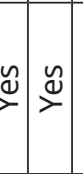 & & $\stackrel{0}{y} \stackrel{y}{\nu}$ & 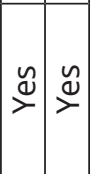 \\
\hline
\end{tabular}

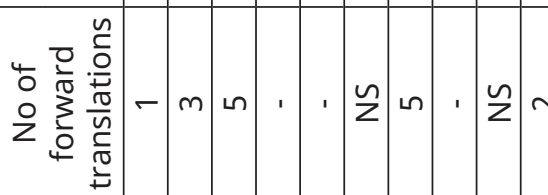

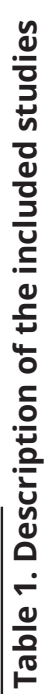
등

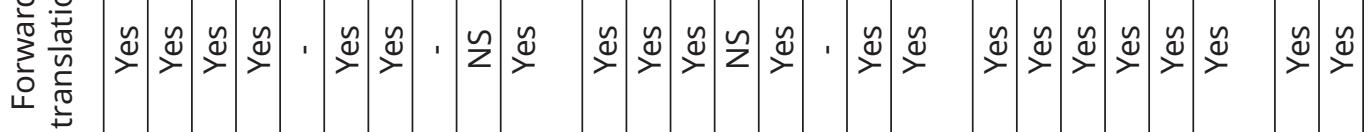

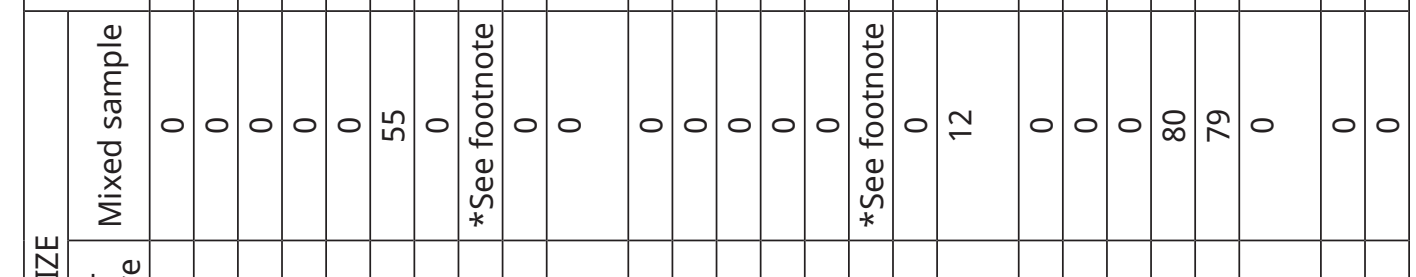

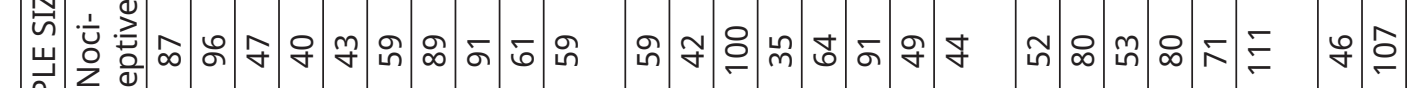
in

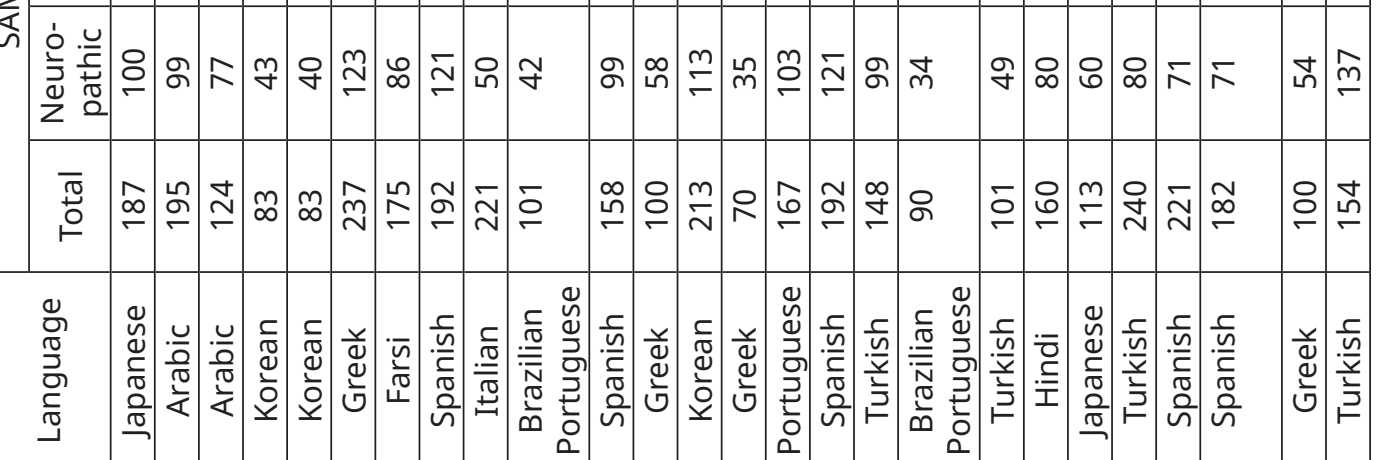

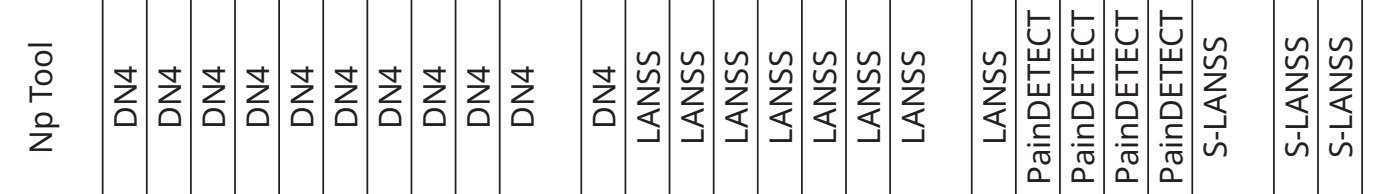




\begin{tabular}{|c|c|c|c|c|c|c|c|c|c|c|c|c|c|}
\hline 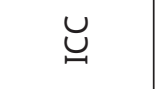 & ஓ् & ஜू. & . & ' & ' & 会 & ' & ' & ' & ' & & $\begin{array}{l}\stackrel{\tilde{N}}{\alpha} \\
\hat{\sigma}\end{array}$ & \\
\hline 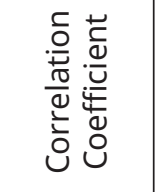 & ' & ' & ' & ' & ' & & ' & ' & ' & ' & & ' & ' \\
\hline 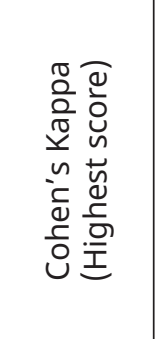 & 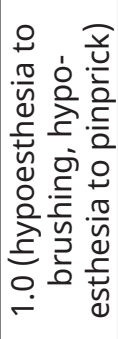 & 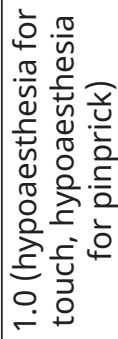 & & ' & 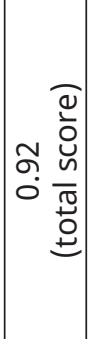 & 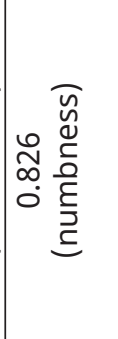 & 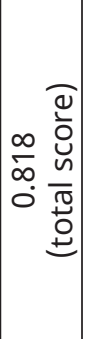 & & ' & 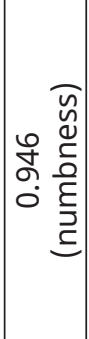 & 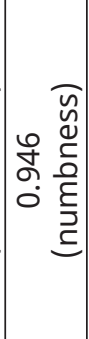 & 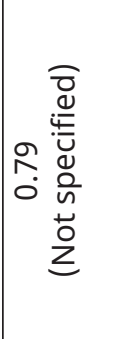 & \\
\hline 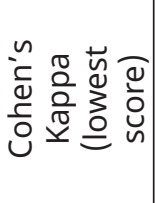 & 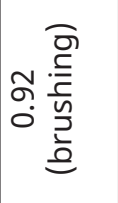 & 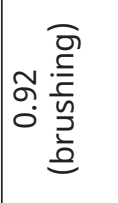 & ' & & 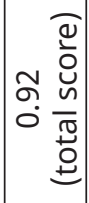 & 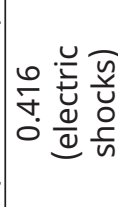 & 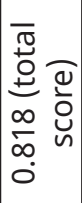 & & ' & 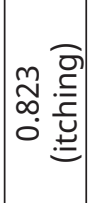 & 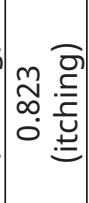 & 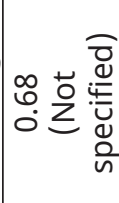 & ' \\
\hline 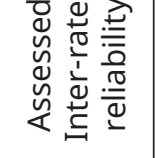 & $\stackrel{\Perp}{\rightleftharpoons}$ & $\stackrel{\check{\Perp}}{\nu}$ & ' & z & 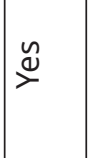 & $\stackrel{\Perp}{\nu}$ & $\stackrel{\check{\Perp}}{\succ}$ & zo & ' & $\stackrel{\Perp}{\nu}$ & 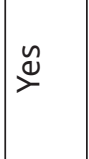 & $\stackrel{\mathscr{y}}{\rightleftharpoons}$ & ㅇ \\
\hline 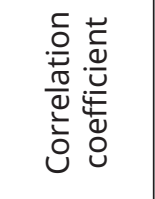 & ' & ' & & 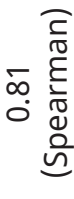 & ' & ' & ' & ' & ' & ' & ' & ' & ' \\
\hline$\underset{\circlearrowright}{\stackrel{*}{U}}$ & , & . & ' & $\begin{array}{l}\bar{\infty} \\
0 \\
0\end{array}$ & ' & $\begin{array}{l}\hat{n} \\
\text { ò } \\
0\end{array}$ & $\begin{array}{l}\stackrel{\leftrightarrow}{n} \\
\hat{O} \\
0\end{array}$ & ' & $\begin{array}{c}\curvearrowright \\
\infty \\
0 \\
0\end{array}$ & 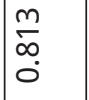 & $\mid \begin{array}{c}m \\
\infty \\
0 \\
0\end{array}$ & $\begin{array}{l}\text { gे } \\
\text { o } \\
0\end{array}$ & . \\
\hline 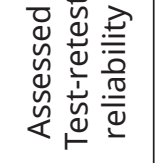 & zo & z & $\stackrel{\mathscr{d}}{>}$ & $\stackrel{\check{y}}{\nu}$ & z & $\stackrel{\mathscr{y}}{\nu}$ & $\stackrel{\check{\Perp}}{\succ}$ & ? & 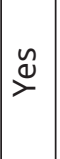 & 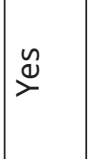 & $\stackrel{\Perp}{\rightleftharpoons}$ & $\stackrel{\check{\nu}}{\succ}$ & ' \\
\hline 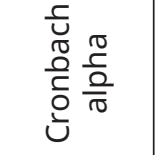 & $\begin{array}{l}m \\
o \\
o \\
+ \\
\text { nn } \\
\text { ñ. } \\
0\end{array}$ & 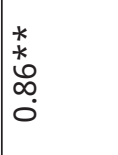 & $\hat{0}$ & $\begin{array}{l}\hat{b} \\
0\end{array}$ & $\stackrel{0}{\stackrel{0}{0}}$ & $\mid \begin{array}{l}0 \\
0 \\
0 \\
0\end{array}$ & $\begin{array}{l}n \\
\stackrel{0}{0} \\
0\end{array}$ & ' & ' & $\begin{array}{l}\sigma \\
\infty \\
0 \\
0\end{array}$ & 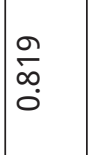 & $\hat{o}$ & \\
\hline 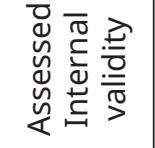 & $\stackrel{\Perp}{\rightleftharpoons}$ & 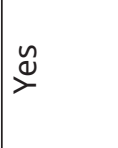 & $\mid \begin{array}{l}\stackrel{y}{\nu} \\
\stackrel{1}{\mid} \mid\end{array}$ & $\stackrel{\check{y}}{>}$ & $\stackrel{\check{y}}{\nu}$ & $\stackrel{\Perp}{\nu}$ & $\stackrel{\check{\Perp}}{\succ}$ & z & $\stackrel{\mathscr{y}}{\nu}$ & 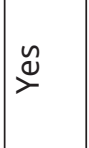 & 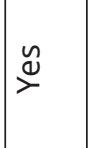 & 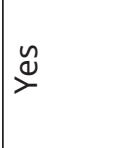 & 은 \\
\hline$\frac{\bar{d}}{\frac{D}{1}}$ & 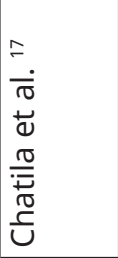 & 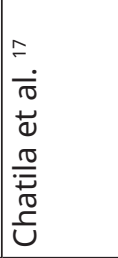 & 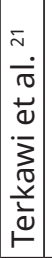 & 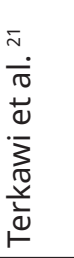 & 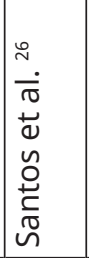 & 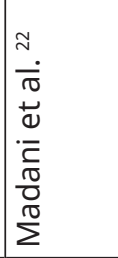 & 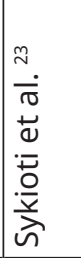 & 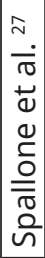 & 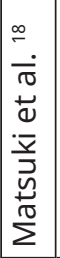 & 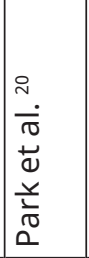 & 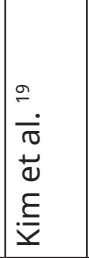 & 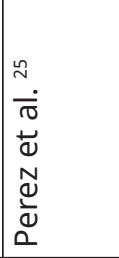 & 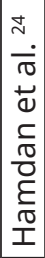 \\
\hline
\end{tabular}


participants [24]. All the included articles that used DN4 instruments were published between 2007 and 2018 (Table 2).

Forward translation was reported in eight studies [17-19, 21-27] with the translation conducted in two studies in 5-times [21,22], one study in 3-times [22], two studies in 2-times $[25,26]$, one study in 1-time [18]. Similarly, backward translation was reported in eight studies [17-19, 21-23, 25, 26]. One study conducted in 3-times [22], three studies conducted in 2-times $[21,25,26]$, three studies were not specific on the number of times backward translation was done, and three studies did not report on the backward translation (Table 2). Expert assessment was involved in seven (7) studies [17, 18, 21-23, 25, 26] and four (4) studies conducted a pilot test $[17,21,22,26]$ (Table 2).

Validity and reliability of the DN4 instrument

Internal validity was reported in nine (9) studies $[17-23,25,26]$ of the included eleven (11) studies (Table 2). Cronbach was reported in eight studies [17, 19-23, 25, 26]. Findings on test-retest validity were reported in seven (7) studies [18-23, 25] with ICC values between 0.81 and 0.96 . One study reported the coefficients of correlation spearman value 0.81 [21]. The inter-rated reliability was conducted in seven (7) studies $[17,19,20,22,23,25,26]$ in translated DN4, Cohen's kappa lowest scored values of 0.92 were reported for brushing in one (1) study [17], while total score values of 0.818 and 0.92 were reported in two (2) studies $[23,26]$, scored values of 0.823 was reported for itching in two studies $[19,20]$ (Table 2).

Cohens kappa high values of 1.0, 0.8260.946 and 0.9 were reported for hypoesthesia to brushing and hypoesthesia to pinprick in two studies $[17,21]$ and numbness $[19,20,22]$. Also, total Cohens kappa highest score values of 0.818 and 0.92 (total score) were reported in two (2) studies $[23,26]$.

Sensitivity, specificity, negative and positive likelihood

Different cut offs were adopted to differentiate the neuropathic pain from nociceptive pain in this instrument (Table 3). Studies included at cut off of 3 showed sensitivity between 93.3-100\%, specificity between $3-100 \%$, Positive Likelihood between 5.2-5.5, Negative Likelihood between 0-3, PPV ranges between $84.3-85.6 \%$ and NPV of $72.1 \%-97.5 \%$ in three studies.

At cut off 4 , sensitivity reported ranges between $80-96 \%$, while the specificity was between 6.8-95\%, Positive likelihood 8.4-20.2 reported in three (3) studies, Negative Likelihood range between 0.1-0.2; PPV was between 63.9$95 \%$ and the NPV was between $69-95.5 \%$ reported in eight (8) studies. At cut off of 5 , sensitivity reported ranges between $75-91 \%$ in four (4) studies, specificity was between $51-99 \%$, Positive likelihood ranged between 5-150, Negative Likelihood was between 0.1-0.2, the PPV was between $84.3-93.7 \%$ and NPV was between $53.2-92.9 \%$. Youden index values with cut off of three ranges between $0.46-0.92$, cut off 4, was between 0.6-0.932 and cut off of 5 ranges between 0.6-0.89 (Table 2).

\section{DN4-interview}

Two studies were included in this review instrument $[17,27]$ conducted in the Arabic and Italian languages respectively (Table 1) and reported between 2012 and 2017 were participants in Arabic, and Italian population with a total sample size of 611 . Patients with neuropathic pain (NP) were 248. The number of nociceptive pain patients' range was 253 patients, and none had mixed pain (MP). Forward translation was conducted in two studies thrice (3-times), and out of the three (3) studies that adopted this DN4-interview, one (1) study was not specific on the conduct and the number of times it was conducted. Similarly, backward translation was conducted in two (2) studies out of the three (3) studies adopted in DN4-interview, but the number of times conducted was not specific. Expert assessment involved, and a pilot study was conducted in two studies included.

Measurement of the validity of DN4interview instrument

Internal validity was assessed in two studies with Cronbach alpha value between 0.55-93 and 0.86 (using Kuder-Richardson formula to assess the internal consistency of the whole questionnaire). In two studies Cohens Kappa lowest score value of 0.92 (brushing) and Cohen's Kappa Highest score values of 0.9 (electric shocks) and 1.0 (Hypoesthesia to brushing, hypoesthesia to pinprick).

Measurement of reliability of DN4-

\section{Interview}

ROC was conducted in two studies included using this instrument (Table 6). At cut off of 2 , the sensitivity was $99 \%$, Specificity value of $58.3 \%$, Positive Likelihood value 2.4, PPV of $71 \%$, NPV of $98.2 \%$. Two studies employ cut off 3 with sensitivity of $97 \%$, Specificity value of between 82-82.3, Positive Likelihood value of 5.5., Negative Likelihood of 0, PPV of $85 \%$ and NPV of $96.3 \%$. One study reported cut off value of 4 with sensitivity value of $84 \%$, Specificity value 
of $90 \%$. Positive Likelihood value of 8.1 , and Negative Likelihood of 0.2, PPV 89.2\% and NPV of $84.3 \%$. Youden index value at cut off of 2 was 0.56 , cut off 3 was 0.79 and cut off 4 was 0.37 .

\section{LANSS}

\section{Description of the LANSS articles}

Demographic characteristic of eight studies included using LANSS instrument in assessment of neuropathic pain (Table 1). Eight (8) studies $[20,24,28-33]$ were included in this review. Two studies each were reported in the Greek [28, 30] and Turkish languages [32,33]. Each of the following languages reported one study Brazilian Portuguese [31], Korean [20], Spanish [24] and Portuguese [29]. Total sample size reported was 1,081. Out of this, 612 were diagnosed with neuropathic pain, while 477 were classified to have nociceptive pain. One study reported $42 \%$ of the neuropathic pain participants also had mixed pain [24]. Forward translation was conducted in four studies twice and one study once. Backward translation was conducted twice in two studies. Four studies conducted backward translation once. Six studies involved expert assessment while four studies conducted pilot studies.

\section{LANSS measurement of validity}

Internal validity assessment was conducted in six studies, with the Cronbach alpha ranging between 0.65-0.96 and the Test-retest reliability conducted in four studies (Table 4). One study reported the intra class coefficient value of 0.77 [28] with Pearson correlation coefficient reported in two studies (0.912-0.990 and 0.940). the inter-rated reliability was reported in two studies $[28,31]$ with Pearson value of 0.87 in one study [28]. ment

Measure of reliability of LANSS instru-

Five studies conducted ROC at cut off of 12 Six (6) cut off values were reported to different neuropathic pain from nociceptive pain. Cut off 2, two (2) studies reported 80.2 and $89.8 \%$, respectively. Specificity was $100 \%$ and $94.2 \%$. One (1) study reported PPV of $93.6 \%$ and NPV of 90.74 . While one (1) study reported Youden index value of 0.8 . Two (2) studies reported cut off 2 , sensitivity was 80.2 and 89.9 , specificity was 94.2 and 100, NPV was 93.6. PPV was 90.74 with Youden index value 0.8. One (1) study reported cut off 7 with sensitivity of $91.2 \%$, Specificity value of $83 \%$, Positive Likelihood of 5.4 , Negative Likelihood value of 0.1 , PPV of $86 \%$ and NPV $89 \%$ with Youden index value of 0.74 .

Cut off of 10.5 was reported in one (1) study with sensitivity of $88 \%$, Specificity of $95 \%$. One
(1) study reported the use of Cut off 11 with sensitivity of $100 \%$, specificity of $95.9 \%$, PPV of 93.6 and NPV of 100 . Four studies used cut off 12 with sensitivity ranging $72.6-98 \%$, specificity range between $74-98 \%$. Negative likelihood was reported in two (2) studies, NPV, at cut of 7 with value 5.4 and cut off 12 with value 36.3 , Negative likelihood value 0.1 at cut off 7 and 0.3 at cut off 12 , the sensitivity range between $72.6-98$, specificity range between 74 98\%. Positive likelihood was reported in a study with value of 36.3 and Negative Likelihood 0.3. Positive Predictive Value range between $85-99 \%$, Negative Predictive Value of $76-96 \%$. One study applied cut off 13 , with sensitivity of $95 \%$, specificity of $98 \%$, PPV of 99 and Negative Predictive $v=$ Value of 90.57 . In addition, one (1) study reported the use of cut off 14 with Sensitivity 84, Specificity 82.8, PPV 88.7 and NPV 76.8.

\section{Self-LANSS}

\section{Description}

Three (3) included studies adopted LANSSself between 2010-2016, one (1) study in the Greek language [28], one study in the Spanish language [38] and one study in the Turkish language [37] (Table 1). Internal validity was reported in three (3) studies with Cronbach alpha between 0.67-0.74. Test-retest validity was reported in two (2) studies with r-coefficient 964-Spearman, 0.97-Pearson, respectively. One (1) study reported inter-rater reliability and second $r$-coefficient. ROC was conducted in three (3) studies [28, 37, 38]. Three (3) different cut offs were used in this study labelled cut off 1 , cut off 2 , cut off 3 , to distinguish neuropathic pain from nociceptive pain.

\section{Reliability}

ROC was conducted in three (3) studies (Table 7.3) with three different cuts off. One (1) study reported cut off 10 with sensitivity $78.8 \%$, Specificity 76.6\%, PPV 81.2\%, NPV 73.9\%. One (1) study adopted Cut off 10.5 , Sensitivity $87 \%$, Specificity $88 \%$, Cut off 11 , Sensitivity $90.1 \%$, Specificity $72.1 \%$, Positive Likelihood value of 3.23, Negative Likelihood value of 0.2, PPV 67.4 and NPV $91.0 \%$ with Youden index value of 0.62. Three (3) studies adopted cut off 12 with sensitivity ranging between $72.3-88.7 \%$, specificity ranging between 78.8-95.2\%, Positive likelihood value of 3.8 and Positive likelihood value 0.2 was recorded in one (1) study (López-de-UraldeVillanueva et al., 2018); PPV ranging between 70.8-96.2\%, NPV between 69.4-91.4\% with Youden index value 0.61 reported in one study. Cut off of 13 showed sensitivity of $81.7 \%$, Specificity $79.3 \%$, Positive likelihood value of 4 , 


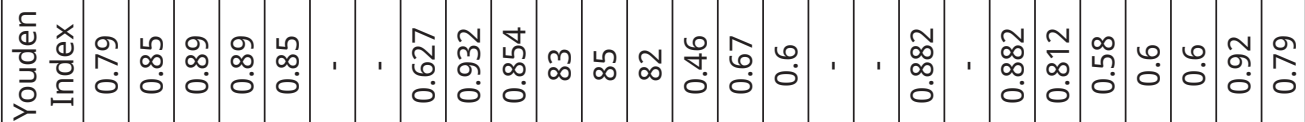

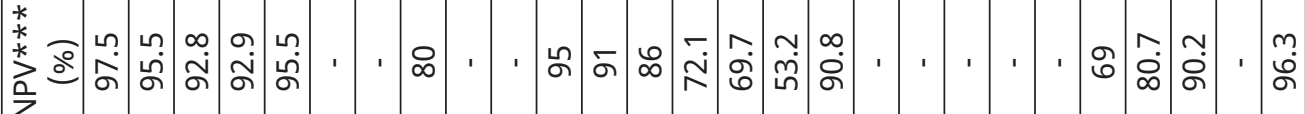

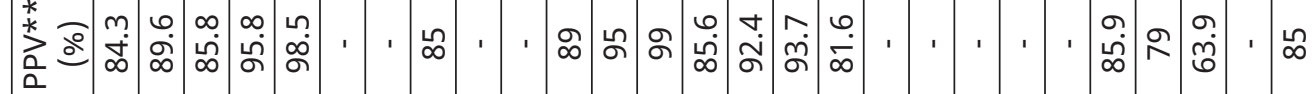

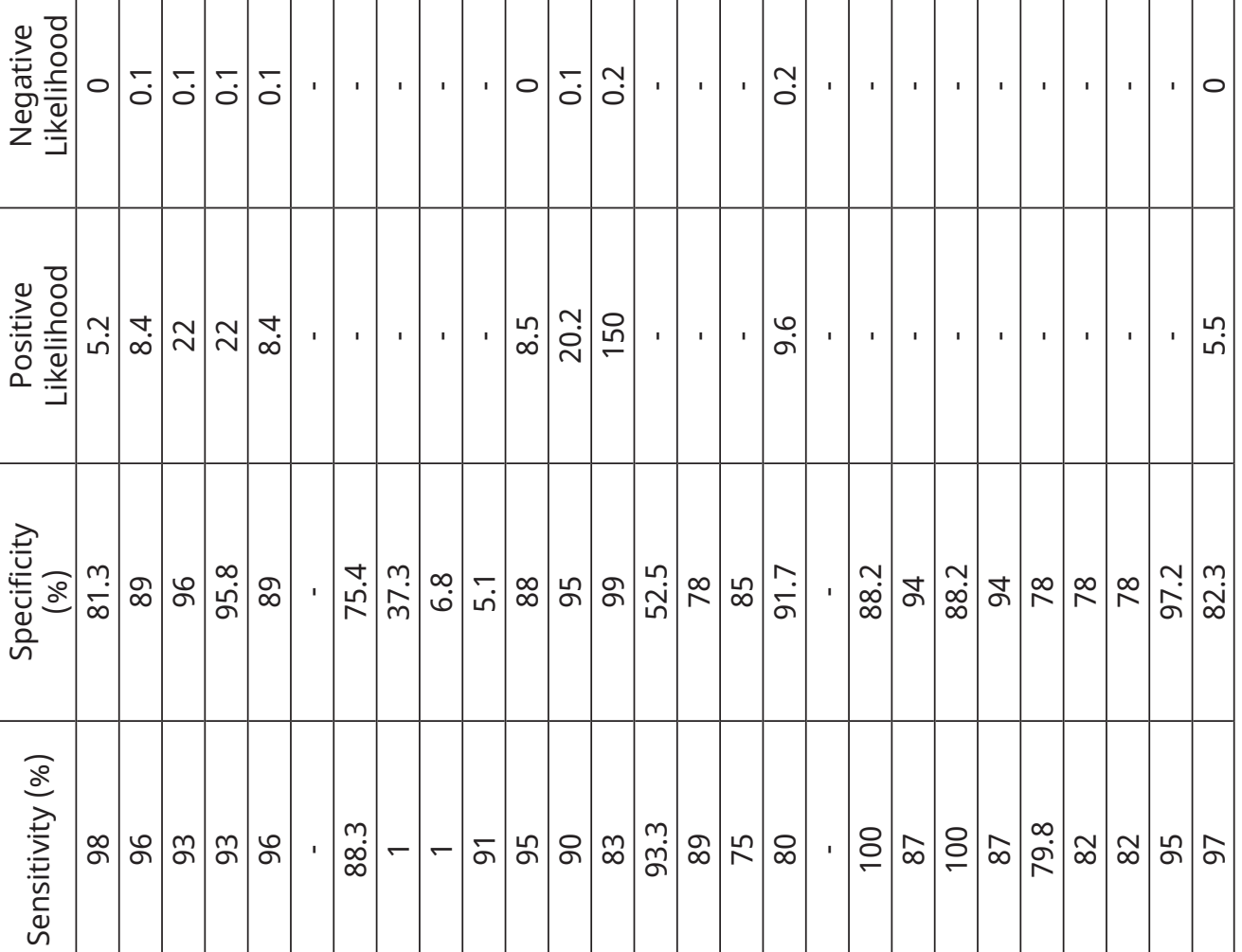

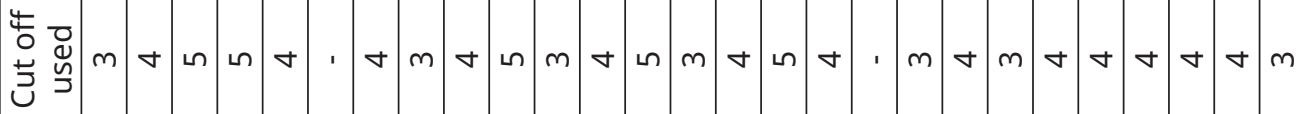

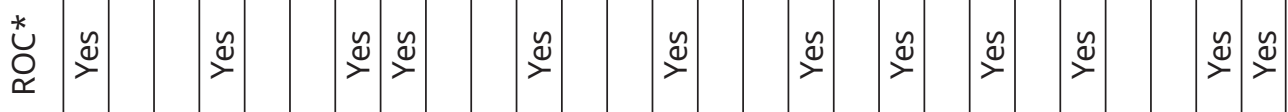



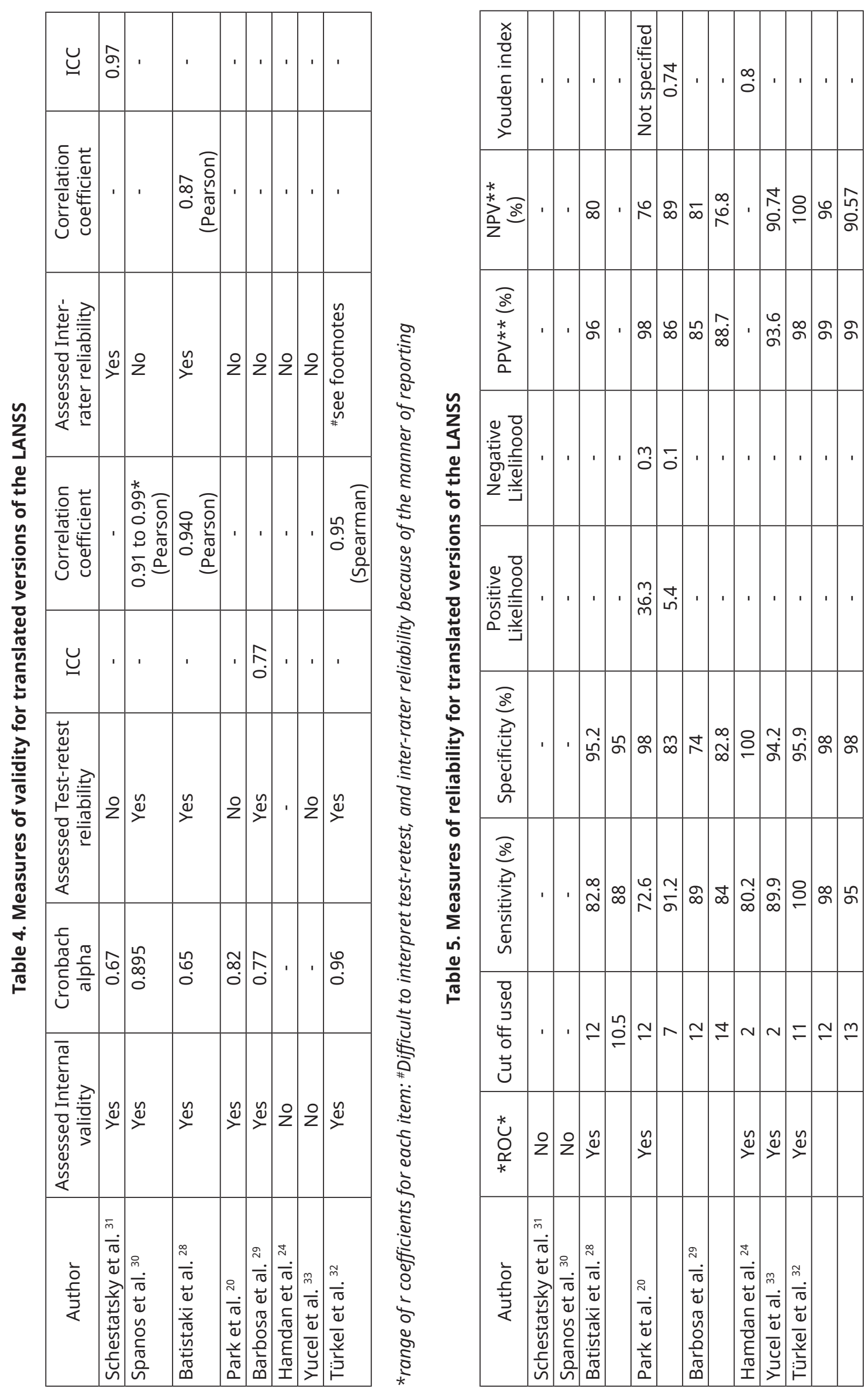
Negative likelihood value of 0.2 , PPV of $71.6 \%$, Negative Predictive value 87.1 with Youden index value of 0.61 .

\section{PainDETECT}

\section{Description}

Four (4) studies were included in the translated original using this instrument between 2012 to 2017 in population with local language Hindi [15], Japanese [36], Spanish [35] and Turkish [34]. Total sample size reported was 974, out of this, 371 participants had neuropathy, 364 and 239 participants were diagnosed with nociceptive and mixed pain respectively. Five (5) studies included reported forward translation, the translation was reported twice in five (5) studies. Backward translation was reported in five (5) studies conducted twice in five studies. Expert assessment was conducted in five studies. Pilot study was conducted in one (1) study [15].

\section{PainDETECT validity characteristic}

Internal validity of the terms was reported in the five (5) studies by Cronbach alpha reported ranges from $0.78-0.86$. Test-retest validity was reported in five (5) studies and ICC reported ranges between 0.934-0.98 in five (5) studies included. Four (4) studies reported ROC $[15,34-36]$.

\section{PainDETECT Reliability characteristic}

Table 8.3: Four cut offs were reported in the studies included using PainDETECT instrument. Cut off 12 , the sensitivity was between $84-93 \%$, Specificity 66-68\%, two studies reported PL 2.7 and 2.9; NL 0.1 and 0.2; PPV was reported by four (4) studies ranging between $73-87 \%$, NPV $65-88 \%$ and Youden index value of 0.575 and 0.519 reported in two studies (Table 3 ).

Two (2) studies made use of cut off 17 , Sensitivity $81 \%$, Specificity 80 and $81 \%$; Positive Likelihood 4.1 and 4.3; Negative predictive value 65 and 81 with Youden index values of 0.613 and 0.624 . One (1) study reported cut off of 18, Sensitivity $83 \%$, Specificity $91 \%$, PPV $90 \%$ and NPV $84 \%$. Three (3) studies adopted cut off of 19 , specificity between $71-79 \%$, Specificity $83-93$ $\%$, Positive likelihood reported in two (2) studies with values of 4 and 4.4, Negative likelihood 0.3 and 0.4 , PPV reported in three (3) studies ranging between $82-90 \%$, NPV between $55-79 \%$ with Youden index reported in two (2) studies of 0.531 and 0.613 (Table 3).

\section{Discussion}

The aim of the study was to conduct a qualitative systematic review to determine the psychometric property of translated, validation and reliability of neuropathic pain screening tools (LANSS, DN4 and PD-Q).

\section{DN4 instrument}

The participants' average sample size was above 30 in all the included studies, and this indicated that all the included studies had the sample size sufficient to represent the population and achieve the aim of the study, and the sample mean on normal distribution. Forward and backward translation were conducted in $90 \%$ of the included studies from local languages (Arabic, Brazillian-Portuguies, Farsi, Greek, Italian, Japanese, Korean and Spanish) into the English language and from English into local languages in the included studies. Tsang et al. [39] reported that this process is an important step in translation, the more times the translation the better chances of avoiding the error of bias. The reported Cronbach alpha value was higher than 0.6 that indicated an acceptable internal consistency among the items and accurate translation with exception of one study [17]. The involvement of expert assessment in over $80 \%$ of the included studies was in agreement with the set-out guidelines for the process of accurate translation [39]. Furthermore, a pilot study was conducted in most of the studies included which is an essential step in determination of the reliability of the items involved in the questionnaire and the validity of the test instrument. The value of Cohen's Kappa was low and high score reported by the pain expert was higher than normal values indicating a profound agreement among the pain experts. The average high sensitivity values and specificity values reported in the instrument pointed to a good validity of this instrument in differentiating neuropathic pain cohort from non-neuropathic pain groups.

The high average value of positive likelihood decreased as the cut off increases. The same pattern of decrease was observed in positive likelihood, however no obvious change in the negative likelihood was evidenced. Positive likelihood and negative likelihood were considered important factors in the measurement of sensitivity and specificity in test population. Considering the reports from the included studies, an optimum value sensitivity, specificity, positive predictive value was reported at cut off 4 at average value, which could make it a better cut off in agreement with Bouhassira et al. [11] in the original development of the DN4 instrument.

\section{DN4-interview}

The participants sample size in this review ( $n=416)$ was greater than 30 in all the included 
studies [17, 27] using DN4-interview instrument; this indicated that all the studies were statistically adequate, and the sample mean was on normal distribution. Forward and backward translation were conducted in $67 \%$ from local languages (Arabic and Italian) to the English language and from English to local languages at least (three times) which were reported as important steps in translation process, as mentioned previously, the more times the translation - the better chances of avoiding the error of bias. Tsang et al. [39] recommended a minimum of twice forward and backward translation for a good translation procedure. There was no specification on the number of times for backward translation that could lead to a possible limitation when using this instrument. The re viewed Cronbach alpha value using this instrument (0.55-0.862) was averagely higher than 0.6 (the minimum Cronbach alpha value for a good internal consistency) that indicated an acceptable internal consistence among the items, a general internal consistency measured (dichotomized measurement of reliability) by the Kuder-Richardson formula (0.86) which is close to 1 as recommended for a good reliability [40] with exception of one study [17].

Moreover, expert assessment in over $80 \%$ of the included studies was also corroborating with the set-out guidelines for the process of adequate translation [39]. Inter-rated reliability review showed a close point (0.9) to 1 in bru shing at low Cohen Kappa and 1 in hypoesthesia to brushing and pinprick. This indicates a high reliability in these two signs of measuring neuropathic pain and shows that this instrument is a good instrument and is consistent among the pain-expert. Therefore, this instrument could be used to distinguish neuropathic pain from non-neuropathic pain.

Pilot study was conducted in most of the studies (67\%) included studies, this is an essential step in determination of the reliability of the items involved in the questionnaire and hence the validity of the test instrument. The optimum sensitivity (84-99\%) and specificity (58-90\%) reported in the instrument pointed to the fact that this instrument (DN4-interview) was a highly sensitive and valid in distinguishing neuropathic pain quality from non-neuropathic pain. Comparing the optimal test scores value of the translated DN4-interview instrument in the included studies with the original DN4interview test score values, the performance of the translated was not as good as the original version.

\section{LANSS}

Our review on the psychometric translation properties using LANSS showed the sample size ( $n=90-213$ ) indicating a good statistical sample. Forward and backward translation were conducted (80\%) for the review [20, 28, 29, 31, 33 ] of the reviewed studies as compared with the original version of LANSS. Test-retest reliability was conducted in $55 \%$ of the studies within the pain experts. Only one study evaluated the intra-class correlation coefficient (0.77) [29]. This is contrary to the expectation from the original version, which showed that the included studies reported Cronbach alpha (0.67-0.9612) higher than 0.6, indicating a good internal consistency among the items. Forward and backward translation were conducted with the instrument good translation procedures in $75 \%$ of the included studies. Fifty percent (50\%) complied with minimum of twice forward translation while twenty percent (20\%) complied with minimum of twice backward translation. This shows that there were gaps in translation procedures in $70 \%$ of the included studies [24, 29, 31-33]. Inter-rated reliability was conducted in $20 \%$ of the included studies, which were considered as an important step in measurement of reliability in instrument testing and the validity of the instrument as compared with original LANSS translation procedure. This is in contrary to the setout procedure for a good neuropathic pain instrument.

The average sensitivity value (85\%) and specificity values (92\%) observed using this instrument indicated that LANSS was a very sensitive instrument and specific to measure the neuropathic components of a pain patient across all languages. Average Positive Predictive value $(93.7 \%)$ showed that the instrument was an effective instrument in the determination of components of LANSS questionnaire that marked out neuropathic pain components. This agrees with the Bennett study on the development of LANSS neuropathic pain screening tool [9].

\section{S-LANSS}

The is a modification of the original LANSS instrument without the clinical examinations that was developed by Bennett et al. [41]. Our review indicated that the internal consistence measured by Cronbach alpha (0.67-0.74) showed high internal consistency among the items included in the instrument in a population sample size of average $(n=145)$, which was statistically dependable sample size. Forward and backward translations were conducted in 


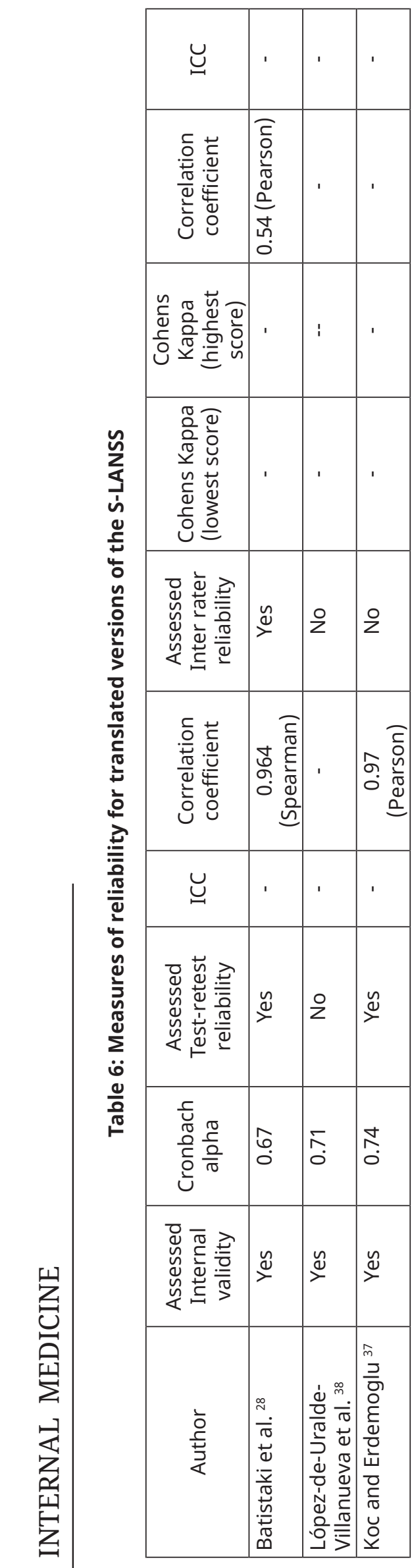

62 T.R. Fagbohun

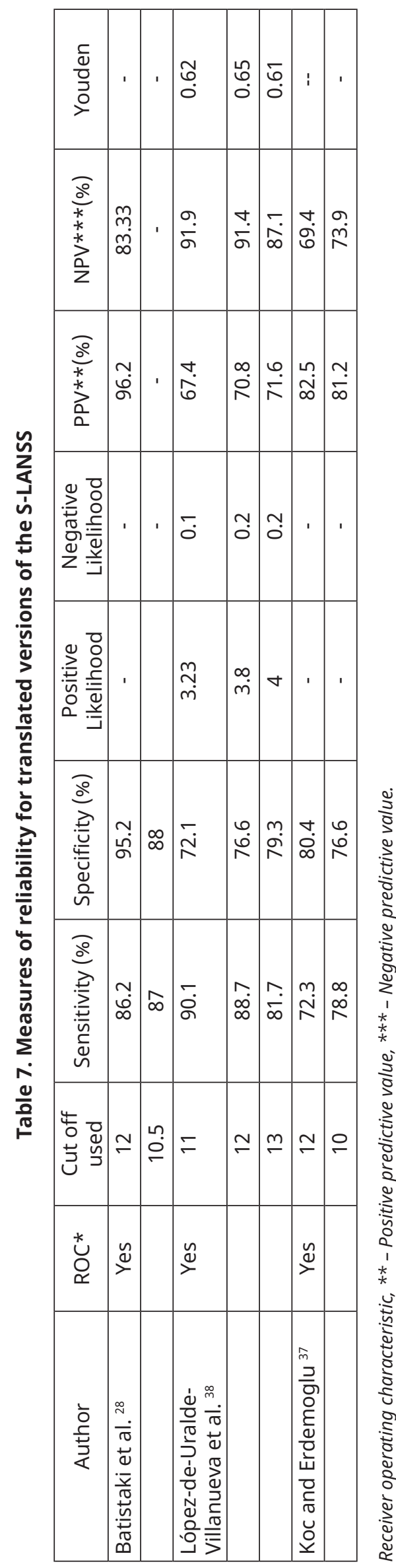

ISSN 2413-6077. IJMMR 2021 Vol. 7 Issue 1 


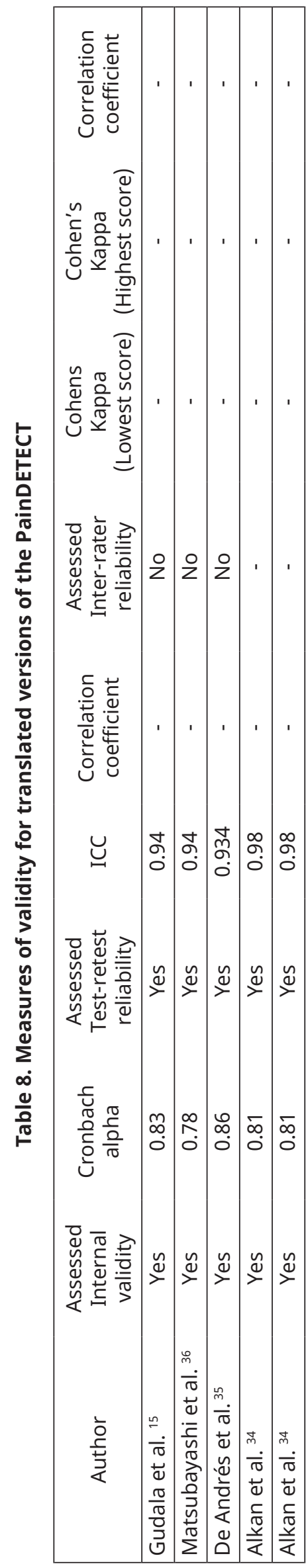

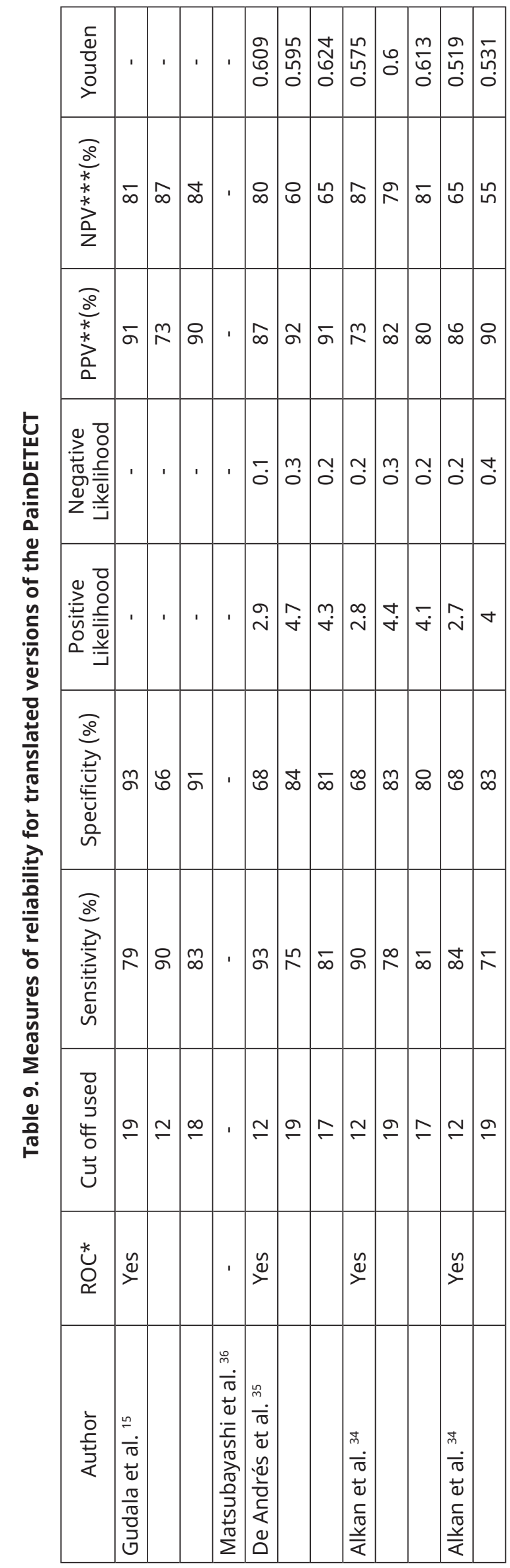


all the studies (two times) that was the minimum number of times it should be carried out; pilot study was conducted with involvement of expert assessment in all the included studies. This review proved Cronbach alpha (0.67-0.74 range) of above 0.6 recommended for a good internal consistency in translation research [42]. However, the Test - retest reliability was conducted $(90 \%)$ of the included article, which is an important procedure to measure good translation procedure. Our review on this instrument showed an average sensitivity value $(83.02 \%)$ and specificity (80.3\%); these values indicated that the instrument was sensitive in determination of the neuropathic component of pain patients. The value of the sensitivity deceased as the cut off value increases from 12 to 13 in a population sample size of 154 [38] in association with decrease in the value of NPV as the cut off value deceased. This review showed an optimum value of sensitivity, specificity, and the positive predictive value at cut off 12 , indicating a high performance of the instrument. This cut off 12 was also reported by the three studies, which could make it an acceptable cut off to distinguish neuropathic pain patients from non-neuropathic pain patients.

\section{PD-Q}

All the included studies conducted forward and backward translation twice (in agreement with the recommended standard). Most of the studies did not conduct any pilot study. This is contrary to the guideline for translation procedures, which is an important primary step. The internal consistency of the items measured by evaluating the Cronbach alpha values (0.780.86) showed a high internal consistency among the items listed on the instrument. Our review showed that Test-retest reliability was conducted in all the included studies with the average value of interclass correlation coefficient (0.95), suggesting a high validity of the instrument in all the translated versions of PD-Q reviewed in the diagnosis of neuropathic pain from non-neuropathic pain. The studies showed an average sensitivity value (82.3\%) and specificity (80.5\%) that indicated that PDQ was a sensitive instrument in the determination of neuropathic pain component, and the items were very specific in the determination of the symptoms of neuropathic pain.

\section{Conclusions}

The original DN4 and LANSS had the most evidence for their psychometric, reliability and validity properties in peer-reviewed articles.
These tools were designed to assess the neuropathic pain quality in a test population through differentiating signs and symptoms between neuropathic and non-neuropathic pain patients. Furthermore, these screening questionnaires may provide an indication of the presence of neuropathic pain quality; however, they cannot replace a clinical assessment. It is clear from the studies that most of the instruments do not assess psychometric, reliability and validity properties effectively. For those that were assessed, not all of them were satisfactory, and most of the findings were supported by low or very low level of evidence. In conclusion, we recommend that both the clinical assessment and neuropathic painscreening tool are pivotal in the diagnosis of neuropathic pain component in pain patients in clinical settings.

\section{Recommendations}

These three neuropathic pain screening tools (DN4, LANSS and PDQ) translated version as performed ultimately well in other local languages at their test population but none of these has been developed in the African Language, it will be a valuable interest also to evaluate the performance of this tool by determining the reliability and validity properties.

To increase the sensitivity, reliability and validity of these screening tools, efforts should be taken to carry out forward and backward translation more than twice from original version of the tools. Additionally, the use of language translation experts in both the original version and the translated local version of the original screening tool should be used for transcription and translation process. Moreover, translation into as many local languages as possible should be made to ensure consistency of the methodology and the properties should be measured by the tools.

This would be especially valuable in the sub-Saharan African region where most of the population might not be proficient in the lingua franca. We have just completed the translation of the DN4 screening tool into Isizulu (a commonly spoken Nguni African language in South Africa) in our research group. In future studies, we will assess the sensitivity, reliability, and validity of this translated version and evaluate its feasibility in line with other previously translated versions.

\section{Conflict of Interests}

There are no conflicts of interest between the author and other researchers that contributed to data extraction. 


\section{Acknowledgements}

My profound gratitude to Professor Peter Kamerman and Dr Antonia Wadley of pain laboratory, School of Physiology, Faculty of Health Sciences, University of Witwatersrand medical school for their intellectual contributions in screening of the articles. I also appreciate the funding support (FRC Funding) from the Faculty of Health Sciences and Professor
William Daniels for funding this research through the NRF supervisor link funding, Wits University, Johannesburg, South Africa.

\section{Autho's Contributions}

Temitope Richard Fagbohun - Conceptualization, methodology, formal data collection and analysis, writing - original draft, writing reviewing and editing.

\section{СИСТЕМАТИЧНИЙ ОГЛЯД МЕТОДІВ ПСИХОМЕТРІЇ, НАДІЙНОСТІ ТА ВАЛІДНОСТІ ПЕРЕКЛАДЕНИХ ОПИТУВАЛЬНИКІВ ДЛЯ СПОСОБІВ СКРИНІНГУ НЕЙРОПАТИЧНОГО БОЛЮ (DN4, LANSS I PDQ) 1 СІЧНЯ 2005 - 19 ЛИПНЯ 2019}

Вступ. Для скринінгу нейропатичного болю використовують різні опитувальники (DN4, LANSS ma $P D Q)$, які були перекладені на декілька локальних мов та валідовані. Щоб визначити надійність цих засобів та їх здатність відрізняти нейропатичний біль від ноцицептивного при діагностиці, було проведено систематичний огляд для синхронізації властивостей та припущення про надійність перекладеної версії цих засобів скринінгу нейропатичного болю.

Мета. Провести обґрунтований систематичний огляд для оцінки психометрії, надійності та валідності DN4, LANSS ma PDQ у період з січня 2005 по 2019 рік.

Методи. Двоє незалежних рецензентів провели пошук відповідних статей у Pubmed, Scopus ma Web of Science на основі критеріїв включення ЈBI (Інститут Джоани Бріггс). Дані, отримані зі статей, були синтезовані у вигляді таблиці.

Результати. В огляд були включені двадиять шість статей з DN4 $(n=11)$, LANSS $(n=8)$ ma PDQ $(n=4)$, перекладених з англійської мови на вісім місцевих мов. Чутливість та специфічність шкали DN4 коливалися від 75\% до 98\% та 37,3\% до 96\% відповідно. Внутрішня надійність (a) перекладеної версії DN4 коливалася в межах 0,55-0,862

Чутливість та специфічність шкали LANSS коливалися від 75\% до 98\% та 37,3\% до 96\% відповідно. Внутрішня надійність (а) перекладеної версії LANSS перебувала в межах 0,67-0,96

Чутливість та специфічність шкали PDQ коливалися від 75\% до 98\% та 37,3\% до 96\% відповідно. Внутрішня надійність (а) перекладеної версії $P D Q$ знаходилася в межах 0,81-0,86.

Висновки. Усі перекладені інструменти продемонстрували хорошу внутрішню узгоденість елементів, високу чутливість та позитивне прогностичне значення, однак не досягали рівня оригіналів. Тому для належної діагностики пацієнтів з нейропатичним болем ці скринінгові інструменти пропонується використовувати разом з клінічним обстеженням.

КЛючОВІ СЛОВА: нейропатичний біль; позитивна ймовірність; негативна ймовірність; позитивне прогностичне значення; негативне прогностичне значення.

Information about the authors

Temitope Richard Fagbohun, Research Student, University of Witwatersrand, Johannesburg, South Africa.

ORCID 0000-0002-3343-7634, e-mail: temitopesms@aol.com

\section{References}

1. Scholz J, Finnerup NB, Attal N, Aziz Q, Baron R, Bennett MI, Benoliel R, Cohen M, Cruccu G, Davis KD, Evers S. The IASP classification of chronic pain for ICD-11: chronic neuropathic pain. Pain. 2019 Jan; 160(1):53.

DOI: $10.1097 /$ j.pain. 0000000000001365
2. Colloca L, Ludman T, Bouhassira D, Baron R, Dickenson AH, Yarnitsky D, Freeman R, Truini A, Attal N, Finnerup NB, Eccleston C. Neuropathic pain. Nature reviews Disease primers. 2017 Feb 16; 3(1):1-9.

DOI: $10.1038 / \mathrm{nrdp} .2017 .2$ 
3. Reinhart L, Knight W, Roberts L, Mendes C. HHS public access global burden of disease study 2010. Lancet. 2012;380(9859):2163-96.

DOI: 10.1016/S0140-6736(12)61729-2.

4. Torta R, Ieraci V, Zizzi F. A review of the emotional aspects of neuropathic pain: from comorbidity to co-pathogenesis. Pain and therapy. 2017 Dec;6(1):11-7.

DOI: $10.1007 / s 40122-017-0088-z$

5. Rienstra W, Blikman T, Dijkstra B, van Raay J, Slager G, Bulstra S, Stevens M, van den AkkerScheek I. Validity of the Dutch modified painDETECT questionnaire for patients with hip or knee osteoarthritis. Disability and rehabilitation. $2019 \mathrm{Apr}$ 10;41(8):941-7.

DOI: $10.1080 / 09638288.2017 .1413429$

6. Dueñas M, Ojeda B, Salazar A, Mico JA, Failde I. A review of chronic pain impact on patients, their social environment and the health care system. Journal of pain research. 2016;9:457.

DOI: $10.2147 / J P R . S 105892$

7. Costigan M, Scholz J, Woolf CJ. Neuropathic pain: a maladaptive response of the nervous system to damage. Annual review of neuroscience. 2009 Jul 21;32:1-32.

DOI: 10.1146/annurev.neuro.051508. 135531

8. Mathieson S, Maher CG, Terwee CB, De Campos TF, Lin CW. Neuropathic pain screening questionnaires have limited measurement properties. A systematic review. Journal of clinical epidemiology. 2015 Aug 1;68(8):957-66.

DOI: $10.1016 / j$.jclinepi.2015.03.010

9. Bennett M. The LANSS Pain Scale: the Leeds assessment of neuropathic symptoms and signs. Pain. 2001 May 1;92(1-2):147-57.

DOI: 10.1016/s0304-3959(00)00482-6

10. Krause SJ, Backonja MM. Development of a neuropathic pain questionnaire. The Clinical journal of pain. 2003 Sep 1;19(5):306-14.

DOI: 10.1097/00002508-200309000-00004

11. Bouhassira D, Attal N, Alchaar H, Boureau F, Brochet B, Bruxelle J, Cunin G, Fermanian J, Ginies P, Grun-Overdyking A, Jafari-Schluep H. Comparison of pain syndromes associated with nervous or somatic lesions and development of a new neuropathic pain diagnostic questionnaire (DN4). pain. 2005 Mar 1;114(1-2):29-36

DOI: 10.1016/j.pain.2004.12.010

12. Portenoy R, ID Pain Steering Committee. Development and testing of a neuropathic pain screening questionnaire: ID Pain. Current medical research and opinion. 2006 Aug 1;22(8):1555-65.

DOI: $10.1185 / 030079906 \times 115702$

13. Freynhagen R, Baron R, Gockel U, Tölle TR. Pain DETECT: a new screening questionnaire to identify neuropathic components in patients with back pain. Current medical research and opinion. 2006 Oct 1;22(10):1911-20.

DOI: $10.1185 / 030079906 \times 132488$

14. Unal-Cevik I, Sarioglu-Ay S, Evcik D. A comparison of the DN4 and LANSS questionnaires in the assessment of neuropathic pain: validity and reliability of the Turkish version of DN4. The Journal of Pain. 2010 Nov 1;11(11):1129-35.

DOI: 10.1016/j.jpain.2010.02.003.
15. Gudala K, Ghai B, Bansal D. Neuropathic Pain Assessment with the Pain DETECT Questionnaire: Cross-Cultural Adaptation and Psychometric EvaIuation to Hindi. Pain Practice. 2017 Nov;17(8): 1042-9.

DOI: $10.1111 /$ papr.12562

16. Moher D, Shamseer L, Clarke M, Ghersi D, Liberati A, Petticrew M, Shekelle P, Stewart LA. Preferred reporting items for systematic review and meta-analysis protocols (PRISMA-P) 2015 statement. Systematic reviews. 2015 Dec;4(1):1-9.

DOI: $10.1186 / 2046-4053-4-1$

17. Chatila N, Pereira B, Maarrawi J, Dallel R. Validation of a new Arabic version of the neuropathic pain diagnostic questionnaire (DN4). Pain Practice. 2017 Jan; 17(1):78-87.

DOI: 10.1111/papr.12419

18. Matsuki Y, Sukenaga N, Miyagi K, Tsunetoh T, Mizogami M, Shigemi K, Maeda L, Hirose M. Reliability and validity of the Japanese translation of the DN4 Diagnostic Questionnaire in patients with neuropathic pain. Journal of anesthesia. 2018 Jun;32(3):403-8.

DOI: $10.1007 / \mathrm{s} 00540-018-2495-7$

19. Kim H-J, Park J-H, Bouhassira D, Shin J-H, Chang B-S, Lee C-K, Baek CH, Yeom JS. Validation of the Korean version of the DN4 diagnostic questionnaire for neuropathic pain in patients with lumbar or lumbar-radicular pain. Yonsei medical journal. 2016;57(2):449.

DOI: $10.3349 / y m j .2016 .57 .2 .449$

20. Park C, Lee YW, Yoon DM, Kim DH. Crosscultural adaptation and linguistic validation of the Korean version of the Leeds assessment of neuropathic symptoms and signs pain scale. Journal of Korean medical science. 2015 Sep 1;30(9):1334-9.

DOI: 10.3346/jkms.2015.30.9.1334

21. Terkawi AS, Backonja MM, Abolkhair A, Almaharbi S, Joy J, Foula F, Alswiti M, Terkawi YS, AlZhahrani T, Alghamdi FS, Tsang S. Development and validation of Arabic version of the Neuropathic Pain Questionnaire-short form. Saudi journal of anaesthesia. 2017 May;11(Suppl 1):S53.

DOI: 10.4103/sja.SJA_86_17.

22. Madani SP, Fateh $\mathrm{HR}$, Forogh $B$, Fereshtehnejad SM, Ahadi T, Ghaboussi P, Bouhassira D, Raissi GR. Validity and reliability of the persian (farsi) version of the DN 4 (douleur neuropathique 4 questions) questionnaire for differential diagnosis of neuropathic from non-neuropathic pains. Pain Practice. 2014 Jun;14(5):427-36.

DOI: $10.1111 /$ papr.12088

23. Sykioti P, Zis P, Vadalouca A, Siafaka I, Argyra E, Bouhassira D, Stavropoulou E, Karandreas N. Validation of the Greek Version of the DN 4 Diagnostic Questionnaire for Neuropathic Pain. Pain Practice. 2015 Sep;15(7):627-32.

DOI: $10.1111 /$ papr.12221

24. Hamdan A, Luna JD, Del Pozo E, Galvez R. Diagnostic accuracy of two questionnaires for the detection of neuropathic pain in the S panish population. European journal of pain. 2014 Jan;18(1):101-9. DOI: $10.1002 / j .1532-2149.2013 .00350 . x$

25. Perez C, Galvez R, Huelbes S, Insausti J, Bouhassira D, Diaz S, Rejas J. Validity and reliability of the Spanish version of the DN4 (Douleur Neuro- 
pathique 4 questions) questionnaire for differential diagnosis of pain syndromes associated to a neuropathic or somatic component. Health and quality of life outcomes. 2007 Dec;5(1):1-0.

DOI: $10.1186 / 1477-7525-5-66$

26. Santos JG, Brito JO, de Andrade DC, Kaziyama VM, Ferreira KA, Souza I, Teixeira MJ, Bouhassira D, Baptista AF. Translation to Portuguese and validation of the Douleur Neuropathique 4 questionnaire. The Journal of Pain. 2010 May 1;11(5):484-90.

DOI: $10.1016 /$ j.jpain.2009.09.014

27. Spallone V, Morganti R, D'amato C, Greco C, Cacciotti L, Marfia GA. Validation of DN4 as a screening tool for neuropathic pain in painful diabetic polyneuropathy. Diabetic Medicine. 2012 May;29(5):578-85.

DOI: $10.1111 / \mathrm{j} .1464-5491.2011 .03500 . x$

28. Batistaki, C., Lyrakos, G., Drachtidi, K., Stamatiou, G., Kitsou, M.C. and Kostopanagiotou, G. 2016. Translation, Cultural Adaptation, and Validation of Leeds Assessment of Neuropathic Symptoms and Signs (LANSS) and Self-Complete Leeds Assessment of Neuropathic Symptoms and Signs (S-LANSS) Questionnaires into the Greek Language. Pain Practice, 16(5), pp.552-564.

DOI: $10.1111 /$ papr.12300

29. Barbosa M, Bennett MI, Verissimo R, Carvalho D. Cross-Cultural Psychometric Assessment of the Leeds Assessment of Neuropathic Symptoms and Signs (LANSS) Pain Scale in the Portuguese Population. Pain Practice. 2014;14(7):620-4.

DOI: 10.1111/papr.12118

30. Spanos K, Lachanas VA, Chan P, Bargiota A, Giannoukas AD. Validation of the Leeds Assessment of Neuropathic Symptoms and Signs (LANSS) questionnaire and its correlation with visual analog pain scales in Greek population. Journal of Diabetes and its Complications. 2015 Nov 1;29(8):1142-5.

DOI: 10.1016/j.jdiacomp.2015.08.008

31. Schestatsky $P$, Félix-Torres $V$, Fagundes Chaves ML, Câmara-Ehlers B, Mucenic T, Caumo W, Nascimento O, Bennett MI. Brazilian Portuguese validation of the Leeds Assessment of Neuropathic Symptoms and Signs for patients with chronic pain. Pain Medicine. 2011 Oct 1;12(10):1544-50.

DOI: $10.1111 /$ j.1526-4637.2011.01221.x

32. Türkel $Y$, Türker $H$, Demir IA, Bayrak AO, Onar MK. Validation of self report version of the Leeds Assessment of Neuropathic Symptoms and Signs score for identification of neuropathic pain in patients from northern Turkey. Adv Clin Exp Med. 2014;23(4):599-603.

DOI: $10.17219 /$ acem/37233

33. Türkel Y, Türker H, Demir İA, Bayrak AO, Onar MK. Validation of self report version of the Leeds Assessment of Neuropathic Symptoms and Signs score for identification of neuropathic pain in pa- tients from northern Turkey. Adv Clin Exp Med. 2014 Jul 1;23(4):599-603.

DOI: $10.17219 /$ acem/37233

34. Alkan H, Ardic F, Erdogan C, Sahin F, Sarsan A, Findikoglu G. Turkish version of the painDETECT questionnaire in the assessment of neuropathic pain: a validity and reliability study. Pain Medicine. 2013 Dec 1;14(12):1933-43.

DOI: $10.1111 /$ pme. 12222

35. De Andrés J, Pérez-Cajaraville J, Lopez-Alarcón MD, López-Millán JM, Margarit C, RodrigoRoyo MD, Franco-Gay ML, Abejón D, Ruiz MA, LópezGomez V. Cultural adaptation and validation of the painDETECT scale into Spanish. The Clinical journal of pain. 2012;28(3):243-53.

DOI: 10.1097/AJP.0b013e31822bb35b

36. Matsubayashi $Y$, Takeshita K, Sumitani M, Oshima Y, Tonosu J, Kato S, Ohya J, Oichi T, Okamoto N, Tanaka S. Validity and reliability of the Japanese version of the painDETECT questionnaire: a multicenter observational study. PLoS One. 2013 Sep 30;8(9):e68013.

DOI: $10.1371 /$ journal.pone.0068013

37. Koc R, Erdemoglu AK. Validity and reliability of the Turkish Self-administered Leeds Assessment of Neuropathic Symptoms and Signs (S-LANSS) questionnaire. Pain Medicine. 2010 Jul 1;11(7):1107-14.

DOI: $10.1111 / j .1526-4637.2010 .00837 . x$

38. López-de-Uralde-Villanueva I, Gil-Martínez A, Candelas-Fernández $\mathrm{P}$, de Andrés-Ares J, BeltránAlacreu $\mathrm{H}$, La Touche R. Validity and reliability of the Spanish-language version of the self-administered Leeds Assessment of Neuropathic Symptoms and Signs (S-LANSS) pain scale. Neurología (English Edition). 2018 Oct 1;33(8):505-14.

DOI: $10.1016 / \mathrm{j} . \mathrm{nrl} .2016 .10 .009$

39. Tsang S, Royse CF, Terkawi AS. Guidelines for developing, translating, and validating a questionnaire in perioperative and pain medicine. Saudi journal of anaesthesia. 2017;11(Suppl 1):S80.

DOI: 10.4103/sja.SJA_203_17

40. Kuder GF, Richardson MW. The theory of the estimation of test reliability. Psychometrika. 1937 Sep;2(3):151-60.

DOI: $10.1007 / \mathrm{BF} 02288391$

41. Bennett MI, Smith BH, Torrance N, Potter J. The S-LANSS score for identifying pain of predominantly neuropathic origin: validation for use in clinical and postal research. The Journal of Pain. 2005 Mar 1;6(3):149-58.

DOI: 10.1016/j.jpain.2004.11.007

42. Taber KS. The use of Cronbach's alpha when developing and reporting research instruments in science education. Research in science education. 2018 Dec;48(6):1273-96.

DOI: $10.1007 / \mathrm{s} 11165-016-9602-2$

Received 20 May 2021; revised 22 Jun 2021; accepted 23 Jun 2021.

This is open access article distributed under the Creative Commons Attribution License, which permits unrestricted use, distribution, and reproduction in any medium, provided the original work is properly cited. 